DOI 10.18551/rjoas.2019-08.30

\title{
GENETIC VARIABILITY, CORRELATION AND PATH ANALYSIS OF RICE GENOTYPES IN RAINFED CONDITION AT LAMJUNG, NEPAL
}

\author{
Bhandari Kamana*, Poudel Ankur, Sharma Subarna \\ Institute of Agriculture and Animal Science, Lamjung Campus, Nepal
}

Kandel Bishnu Prasad

Department of Plant Breeding, Postgraduate Program, Institute of Agriculture and Animal

Science, Tribhuvan University, Kirtipur, Nepal

\author{
Upadhyay Koshraj \\ Institute of Agriculture and Animal Science, Gauradaha Campus, Nepal
}

*E-mail: kamana.vandari@gmail.com

\begin{abstract}
An experiment on eleven rice genotypes was designed at field of Institute of Agriculture and Animal Science (IAAS), Lamjung, under Randomized Complete Block Design (RCBD) with three replications from June-October, 2018 to study genetic variability and character association. Analysis of variance showed significant difference among the genotypes for all the characters studied except for fertility percent which indicates the existence of sufficient genetic variability and potential for selection and further improvement. Grain yield was significantly positively correlated with panicle length while positively and non-significantly correlated with days of flowering, leaf area and straw yield however negative non-significant association with plant height, soil plant analyzer development (SPAD), fertility percent, thousand grain weight and effective tillers. Leaf area had maximum positive direct effect on grain yield followed by panicle length, thousand grain weight and effective tillers which indicates help for selection and improvement of rice genotypes. The higher value of correlation between panicle length and grain yield is due to the direct effect of panicle length which exhibit true relationship between them. The variability study showed that there was high genotypic coefficient of variation (GCV) and phenotypic coefficient of variation (PCV) for thousand grain weight. High heritability estimates coupled with high genetic advance as per percentage of mean (GAM) was found for thousand grain weight, days of flowering, leaf area and effective tillers which indicate the control of additive gene of action and a greater scope of selection for crop improvement. Khumal 7, Khumal 8 and NR11115-B-B-31-3 were three top performer rice genotypes at Lamjung condition.
\end{abstract}

\section{KEY WORDS}

Genetic advance, genotypic coefficient of variation, heritability, phenotypic coefficient.

Rice (Oryza sativa L.) is one of the important staple cereal crop feeding more than 3.5 billion global population (IRRI, 2017). It is the predominant staple food crop in Nepal and ranks first in position in terms of production and productivity thus contributed significantly to livelihood of majority of people (Tiwari et al., 2018). The production area, production and productivity of Lamjung district were recorded to be 14, 059 ha, 37, 772 ton \& 2.687 ton ha ${ }^{-1}$ respectively (MoAD, 2015/16). Majority of people depend on rainfed agriculture system and in this system drought is the major limiting abiotic stress that reduces productivity by $13-35 \%$ (Rosegrant et al., 2002). Yield is very low in rainfed rice compared to favorable growing conditions. Early or late maturing rice genotypes could be potential alternative to overcome the drought effects under rainfed rice growing conditions. The variability, heritability and genetic advance on different traits of rice are necessary for developing appropriate breeding and selection strategies to increase yield. To overcome yield reduction under rainfed and upland conditions, breeding objective should be targeted for development of drought tolerant 
cultivars. The aim of this research was to evaluate rice genotypes in order to their genetic variability, character association in rainfed condition.

\section{MATERIALS AND METHODS OF RESEARCH}

Eleven rice genotypes (viz. Khumal 13, NR-B-B-31-3, IR87760-15-2-3-4, NR-11032-BB-5-3, NR-11130-B-B-B-12, NR-11289-B-16-1, NR-11137-B-B-10, Khumal 7, Khumal 4, Khumal 8, Anadi (Loca check)) was carried out in RCBD with 3 replications in a field of IAAS, Lamjung. The size of each block was $2 \mathrm{~m} \times 1 \mathrm{~m}$ and spacing between row to row and plant to plant was $20 \mathrm{~cm} \times 20 \mathrm{~cm}$. The distance between two plots is $50 \mathrm{~cm}$ and distance between two replications was $1 \mathrm{~m}$. Each hill consists of $2-3$ seedlings. Nitrogen $60 \mathrm{~kg} \mathrm{ha}^{-1}$, phosphorous $20 \mathrm{~kg} \mathrm{ha}^{-1}$, potassium $20 \mathrm{~kg} \mathrm{ha}^{-1}$ as general recommendation for rainfed low land condition. Half dose of nitrogen and full dose of phosphorous and potash was applied as a basal dose at transplanting and remaining half dose nitrogen was applied as split doses at 30 days after transplanting (DAT) and 45 DAT. Five plants were randomly selected from each plot in each replication and their means were used for the statistical analyses. Observations were recorded on different traits like plant height $(\mathrm{cm})$, leaf area $\left(\mathrm{cm}^{2}\right)$, chlorophyll content, effective tillers $/ \mathrm{m}^{2}$, flowering days, panicle length $(\mathrm{cm}), 1000$ grain weight $(\mathrm{g})$, grain yield $(\mathrm{kg}$ $\left.\mathrm{ha}^{-1}\right)$ and straw yield $\left(\mathrm{kg} \mathrm{ha}^{-1}\right)$.

Phenotypic and Genotypic coefficients of variation were calculated by the method suggested by Lush (1940) and Chaudhary and Prasad (1968).

$$
\begin{gathered}
\text { Phenotypic coefficient of variation }(P C V)=\frac{\text { Phenotypic Standard Deviation }}{\text { General mean }} \times 100 \\
\text { Genotypic coefficient of variation }(G C V)=\frac{\text { Genotypic Standard Deviation }}{\text { General mean }} \times 100
\end{gathered}
$$

According to Sivasubramanian and Menon (1973) PCV and GCV values more than $20 \%$ are regarded as high, whereas values less than $10 \%$ are considered to be low and values between 10 and $20 \%$ to be moderate.

Heritability was calculated by the formula given by Falconer (1996) which is as below:

$$
\mathrm{H}=\frac{v g}{v p} \times 100
$$

Where: $\mathrm{H}=$ heritability in broad sense; $\mathrm{Vp}=$ phenotypic variance; $\mathrm{Vg}=$ genotypic variance.

The heritability percentage categorized as low, moderate and high as followed by (Robinson et al., 1949) as follows: 0 - 30\% Low; $30-60 \%$ Moderate; > 60\% High.

Under selection expected genetic advances where for each character at $5 \%$ selection intensity was computed by the formula described by Johnson et al. (1955).

$$
\text { Genetic Advance }(G A)=k \sigma_{p} . H
$$

Where: $\mathrm{k}=$ constant (selection differential where $\mathrm{k}=2.056$ at $5 \%$ selection intensity); $\sigma_{p}=$ phenotypic standard deviation; $H=$ broad sense heritability.

Genetic advances as percent of mean was calculated to compare the extent of predicted advances of different traits under selection, using the formula $G A M=\frac{G A}{X} \times 100$ (Falconer, 1996), where GAM=genetic advances as percent of mean, GA = genetic advances under selection, $X=$ mean of population in which selection will be employed.

\section{RESULTS AND DISCUSSION}

\section{Mean performance of different traits of rice genotypes}

Plant height $(\mathrm{cm})$. Significant result was observed for plant height and Khumal-4, khumal-7 and NR11137-B-B-10 were found to be significantly superior to all others 
genotypes and statistically at par with NR11115-B-B-31-3, NR11130-B-B-B-12 and NR11289-B-16-1.The average mean value was 139.53 whereas check value was 139.72 .

Leaf area $\left(\mathrm{cm}^{2}\right)$. Significant result was observed. Check value was found to be significantly superior to other genotypes whereas Khumal 13 was found to be lowest. The average mean value was 35 .

SPAD60. Significant result was observed. Khumal 13 was found to be significantly superior and statistically at par with IR87760-15-2-3-4, NR11032-B-B-5-3, NR11130-B-B-B12 and Khumal 8.The check variety value was 31.02. The average mean value was 34.36.

Effective tiller $/ \mathrm{m}^{2}$. Significant result was observed. Khumal 13 was found to be significantly superior and statistically at par with NR11289-B-16-1, Khumal 4 and Khumal 8. NR11032-B-B-5-3 and check variety showed least effective tiller. The average mean value was 34.36.

Days of flowering. Significant result was observed. Khumal 13 showed early flowering nature and statistically at par with NR11130-B-B-B-12. showed late flowering nature. The average mean value was 94.7 .

Table 1 - Mean performance of rice genotypes

\begin{tabular}{|c|c|c|c|c|c|}
\hline Genotypes & $\mathrm{PH}(\mathrm{cm})$ & $\mathrm{LA}\left(\mathrm{cm}^{2}\right)$ & SPAD & NET & DAF \\
\hline Khumal 13 & $118.14^{\mathrm{d}}$ & $24.16^{\mathrm{e}}$ & $40.8^{a}$ & $246.6^{a}$ & $79.6^{\dagger}$ \\
\hline NR11115-B-B-31-3 & $143.9^{\mathrm{abc}}$ & $34.29^{\mathrm{bcd}}$ & $34.02^{\mathrm{bc}}$ & $143.3^{\text {cd }}$ & $88.3^{\mathrm{de}}$ \\
\hline IR87760-15-2-3-4 & $120.26^{\mathrm{d}}$ & $35.64^{\mathrm{bc}}$ & $37.19^{\text {abc }}$ & $205^{b}$ & $89.6^{\mathrm{d}}$ \\
\hline NR-11032-B-B-5-3 & $135.4^{\mathrm{C}}$ & $30.5^{\text {cde }}$ & $38.34^{\mathrm{ab}}$ & $135^{\mathrm{d}}$ & $86.6 d^{e}$ \\
\hline NR-111130-B-B-B-12 & $143.7^{\mathrm{abc}}$ & $26.4^{\mathrm{de}}$ & $35^{\mathrm{abc}}$ & $180^{\mathrm{bc}}$ & $83.3 \mathrm{ef}$ \\
\hline NR11289-B-16-1 & $153.81^{\mathrm{ab}}$ & $35.2^{\mathrm{bc}}$ & $32.27^{\mathrm{bc}}$ & $207^{\mathrm{ab}}$ & $96.6 \mathrm{bc}$ \\
\hline NR11137-B-B-10 & $156.36^{\mathrm{a}}$ & $38.05^{\mathrm{bc}}$ & $31^{\mathrm{c}}$ & $205^{b}$ & $96.6 \mathrm{bc}$ \\
\hline Khumal 7 & $138.6^{\mathrm{a}}$ & $40.2^{b}$ & $32.3^{\mathrm{bc}}$ & $191.6^{b}$ & $92 \mathrm{~cd}$ \\
\hline Khumal 4 & $157.4^{\mathrm{a}}$ & $34.6^{\mathrm{bcd}}$ & $31.5^{\mathrm{c}}$ & $215^{\mathrm{ab}}$ & $92.3 \mathrm{~cd}$ \\
\hline Khumal 8 & $127.4^{\text {cd }}$ & $33.6^{\text {bcde }}$ & $34.4^{\mathrm{abc}}$ & $208.33^{\mathrm{ab}}$ & $100.66 \mathrm{~b}$ \\
\hline Anadi & $139.72^{\mathrm{DC}}$ & $51.9^{\mathrm{a}}$ & $31.02^{c}$ & $137.3^{\mathrm{d}}$ & $136.67 a$ \\
\hline Grand mean & 139.53 & 35 & 34.36 & 188.6 & 94.7 \\
\hline $\mathrm{CV}(\%)$ & 6.24 & 14.31 & 10.11 & 11.1 & 3.47 \\
\hline $\mathrm{LSD}(0.05)$ & 14.83 & 8.53 & 5.92 & 35.67 & 5.6 \\
\hline $\mathrm{F}$ test & $* *$ & ** & * & ** & ** \\
\hline
\end{tabular}

** significant at $1 \%$ level , * significant at $5 \%$ level, $P H=$ Plant height, $L A=$ Leaf area SPAD= Chloraphyll content of leaf, $N E T=$ No. of effective tiller per $m^{2}, D A F=$ Days of flowering.

Grain Yield (ton ha ${ }^{-1}$ ). Significant result was observed among tested rice genotypes. Khumal 8, Khumal 7 and NR11115-B-B-31-3 were three top yielder genotypes whereas the lowest grain yield was found in NR-11130-B-B-B-12. The average mean value was 5.09.

Fertility percentage. Significant result was not observed. The highest fertility percentage was found in NR11289-B-16-1 whereas the lowest value was found in check variety (Anadi). The average mean value was 87.2 .

Table 2 - Mean performance of rice genotypes

\begin{tabular}{|c|c|c|c|c|c|}
\hline Genotypes & GY (ton ha ${ }^{-1}$ ) & ST (ton ha ${ }^{-1}$ ) & TGW (g) & $\mathrm{F}(\%)$ & $\mathrm{PL}(\mathrm{cm})$ \\
\hline Khumal 13 & $4.28^{\text {cde }}$ & $4.16^{\mathrm{d}}$ & $30.06^{b}$ & 90.9 & $19.64^{\mathrm{e}}$ \\
\hline NR11115-B-B-31-3 & $5.83^{\mathrm{ab}}$ & $5.38^{\mathrm{bd}}$ & $22.93^{\text {cde }}$ & 90.4 & $25.57^{\mathrm{cd}}$ \\
\hline IR87760-15-2-3-4 & $5.40^{\mathrm{abc}}$ & $5.83^{\mathrm{abcd}}$ & $22.93^{\text {cde }}$ & 80.4 & $29.28^{\mathrm{ab}}$ \\
\hline NR-11032-B-B-5-3 & $5.11^{\mathrm{abcd}}$ & $4.40^{\mathrm{cd}}$ & $41.03^{\mathrm{a}}$ & 87.2 & $25.6^{\mathrm{cd}}$ \\
\hline NR-11130-B-B-B-12 & $3.63^{\mathrm{e}}$ & $6.16^{\mathrm{abcd}}$ & $23.93^{\mathrm{cd}}$ & 89.8 & $24.2^{\mathrm{cd}}$ \\
\hline NR11289-B-16-1 & $5.23^{\mathrm{abcd}}$ & $5.00^{\mathrm{bcd}}$ & $20.6^{e}$ & 92.6 & $25.5^{\mathrm{cd}}$ \\
\hline NR11137-B-B-10 & $4.71^{\text {bcde }}$ & $6.51^{\mathrm{ab}}$ & $22.5^{\text {de }}$ & 87.2 & $23.2^{d}$ \\
\hline Khumal 7 & $6.12^{\mathrm{a}}$ & $5.65^{\mathrm{bcd}}$ & $28.83^{b}$ & 87.4 & $24.9^{\text {cd }}$ \\
\hline Khumal 4 & $5.33^{\mathrm{abc}}$ & $6.43^{\mathrm{abc}}$ & $20.4^{\mathrm{e}}$ & 89.73 & $27.1^{\mathrm{bc}}$ \\
\hline Khumal 8 & $6.21^{\mathrm{a}}$ & $5.72^{\mathrm{bcd}}$ & $25.5^{\mathrm{c}}$ & 84.02 & $30.15^{a}$ \\
\hline Anadi & $4.11^{\mathrm{de}}$ & $8.00^{\mathrm{a}}$ & $28.73^{b}$ & 79.23 & $22.97^{d}$ \\
\hline Grand mean & 5.09 & 5.75 & 26.14 & 87.2 & 25.3 \\
\hline $\mathrm{CV}(\%)$ & 13.15 & 19.65 & 5.6 & 7.34 & 6.19 \\
\hline $\operatorname{LSD}(0.05)$ & 1.13 & 1926.272 & 2.49 & 10.91 & 2.66 \\
\hline $\mathrm{F}$ test & ** & * & $\star \star *$ & ns & $* *$ \\
\hline
\end{tabular}

** significant at 1 level, * significant at $5 \%$ level, ns= non-significant, GY= Grain yield, ST= Straw yield, TGW= Thousand kernel weight, $P L=$ Panicle length and $F=$ Fertility percentage. 
Straw yield (ton $\mathrm{ha}^{-1}$ ). Significant result was observed. Check variety showed significantly superior and statistically at par with IR87760-15-2-3-4, NR11130-B-B-B-12, NR11137-B-B-10 and Khumal 4. Khumal 13 showed least straw yield. The average mean value was 5.75 .

Thousand grain weight $(g)$. Significant result was observed. NR11032-B-B-5-3 showed highly significant value than other genotypes and Khumal 4 and NR11289-B-16-1 showed least thousand grain weight. The check variety value was 28.73 and the average mean value was 26.14.

Panicle length $(\mathrm{cm})$. Significant result was observed. Panicle length of Khumal 8 was found to be significantly superior and statistically at par with IR87760-15-2-3-4. Khumal 13 had least panicle length. The check variety value was 22.97 and average mean value was 25.30 .

\section{Character association studies}

The result showed that panicle length $\left(0.823^{\star *}\right)$ was significant positive correlation with grain yield whereas leaf area (0.349), straw yield (0.085) and days of flowering (0.12) were positive correlation with grain yield. Plant height (-0.073), SPAD $(-0.25)$, fertility percent ($0.432)$, thousand grain weight $(-0.046)$ and effective tillers $(-0.062)$ were negative correlation with grain yield. In this experiment, panicle length was highly significant positive correlated with grain yield. Similar results were reported earlier in rice by several workers in various character viz. for the association of grain yield and panicle length by Chandra et al. (2009) and Gautam et al. (2018). Therefore, these characters need to be considered for selection. Grain yield had positive correlation with leaf area, straw yield and days of flowering. In relation with days of flowering, similar results were reported by Madhavilatha et al. (2005). Similar results was reported by Marasis et al. (1980) for effective tillers.

Thousand grain weight $(-0.046)$, plant height $(-0.073)$, SPAD $(-0.25)$ and effective tillers $(-0.062)$ were negative correlation with grain yield. In relation with thousand grain weight, similar results was reported by Surek and Beser (2005).Contrast findings were reported by Chandra et al. (2009) and Shamsudddin (1986).In relation with plant height, similar results were reported by Senapati et al. (2009) and Hairmansis et al. (2010) which reveals that tallness in rice reduces the grain yield due to high accumulation of photosynthates on elongation of vegetative parts rather than reproductive parts and selection is devised on semi dwarf genotypes. However, contrast with (Kole and Hasib, 2008). Grain yield had positive correlation with leaf area, straw yield. Similar results were also reported in earlier research performed by Konate et al. (2016) for straw yield.

Table 3 - Correlation coefficient analysis

\begin{tabular}{|c|c|c|c|c|c|c|c|c|c|c|}
\hline & PH & LA & SPAD & PL & F\% & TGW & NET & DAF & GY & SY \\
\hline PH & 1 & & & & & & & & & \\
\hline LA & 0.265 & 1 & & & & & & & & \\
\hline SPAD & $-.782^{\star \star}$ & $-.710^{*}$ & 1 & & & & & & & \\
\hline PL & -0.046 & 0.077 & -0.153 & 1 & & & & & & \\
\hline F\% & 0.403 & $-.626^{*}$ & 0.094 & -0.321 & 1 & & & & & \\
\hline TGW & -0.426 & -0.096 & 0.523 & -0.24 & -0.166 & 1 & & & & \\
\hline NET & -0.166 & -0.419 & 0.186 & -0.051 & 0.289 & -0.424 & 1 & & & \\
\hline DAF & 0.172 & $.897^{\star *}$ & -0.598 & 0.012 & $-.642^{*}$ & -0.038 & -0.39 & 1 & & \\
\hline GY & -0.073 & 0.349 & -0.25 & $.823^{* *}$ & -0.432 & -0.046 & -0.062 & 0.12 & 1 & \\
\hline SY & 0.368 & $.764^{\star *}$ & $-.732^{*}$ & 0.075 & -0.584 & -0.369 & -0.274 & $.773^{\star *}$ & 0.085 & 1 \\
\hline
\end{tabular}

** Correlation is significant at the 0.01 level (2-tailed). * Correlation is significant at the 0.05 level (2-tailed). $P H=$ Plant height $(\mathrm{cm}), L A=L$ eaf area at 60 Days of Transplanting $\left(\mathrm{cm}^{2}\right), S P A D=$ Chlorophyll at 60 DAT, $P L=$ Panicle length $(\mathrm{cm}), F(\%)=$ Fertility percent, TGW=Thousand Grain Weight $(\mathrm{g}), N E T=E f f e c t i v e$ tillers per $m^{2}$, $D A F=$ Days of $50 \%$ flowering, GY=Grain yield (ton ha ${ }^{-1}$ ), ST=Straw yield (ton ha ${ }^{-1}$ ).

Path analysis shows the direct and indirect effect on total yield. Leaf area (0.849) shows highest positive direct effect on grain yield followed by panicle length (0.72), thousand grain weight $(0.343)$ and effective tillers per $\mathrm{m}^{2}(0.238)$. Highest negative direct effect is shown by days of flowering $(-0.74)$ followed by straw yield $(-0.32)$, SPAD $(-0.249)$, plant 
height $(-0.209)$ and fertility percent $(-0.2034)$.The highest total grain yield is panicle length ( 0.82 ) followed by leaf area (0.34), days of flowering (0.12) and straw yield (0.08).Same result was observed for plant height (Prasad et al., 2001).Panicle length, leaf area, days of flowering and straw yield shows direct effect on grain yield so these character may be considered important for crop improvement. Agahi et al. (2007) reported number of effective tillers per plant recorded positive direct effect on grain yield and was in confirmation with our findings.

Table 4 - Path coefficient analysis showing direct (bold) and indirect effects of various traits in grain yield

\begin{tabular}{|c|c|c|c|c|c|c|c|c|c|}
\hline & $\mathrm{PH}(\mathrm{cm})$ & $\mathrm{LA}\left(\mathrm{cm}^{2}\right)$ & SPAD & $\mathrm{PL}(\mathrm{cm})$ & $F(\%)$ & TGW (g) & NET & DAF & $S Y\left(\right.$ ton $\left.\mathrm{ha}^{-1}\right)$ \\
\hline$\overline{\mathrm{PH}(\mathrm{cm})}$ & -0.21 & -0.06 & 0.16 & 0.01 & -0.08 & 0.09 & 0.03 & -0.04 & -0.08 \\
\hline $\mathrm{LA}\left(\mathrm{cm}^{2}\right)$ & 0.23 & 0.85 & -0.60 & 0.07 & -0.53 & -0.08 & -0.36 & 0.76 & 0.65 \\
\hline SPAD & 0.46 & 0.41 & -0.58 & 0.09 & -0.06 & -0.31 & -0.11 & 0.35 & 0.43 \\
\hline$\overline{\mathrm{PL}(\mathrm{cm})}$ & -0.03 & 0.06 & -0.11 & 0.72 & -0.23 & -0.17 & -0.04 & 0.01 & 0.05 \\
\hline$F(\%)$ & -0.08 & 0.13 & -0.02 & 0.07 & -0.20 & 0.03 & -0.06 & 0.13 & 0.12 \\
\hline TGW (g) & -0.15 & -0.03 & 0.18 & -0.08 & -0.06 & 0.34 & -0.15 & -0.01 & -0.13 \\
\hline NET & -0.04 & -0.10 & 0.04 & -0.01 & 0.07 & -0.10 & 0.23 & -0.09 & -0.06 \\
\hline DAF & -0.13 & -0.67 & 0.44 & -0.01 & 0.48 & 0.03 & 0.29 & -0.74 & -0.57 \\
\hline SY (ton ha ${ }^{-1}$ ) & -0.12 & -0.25 & 0.24 & -0.02 & 0.19 & 0.12 & 0.09 & -0.25 & -0.32 \\
\hline Total & -0.07 & 0.35 & -0.25 & 0.82 & -0.43 & -0.05 & -0.06 & 0.12 & 0.09 \\
\hline
\end{tabular}

$P H=$ Plant height, $L A=$ Leaf area at 60 days of transplanting $(D A T), S P A D=$ Chlorophyll content, NET = Effective tiller per $m^{2}, F=$ Fertility percent, $P L=$ Panicle length $D A F=$ Days of $50 \%$ flowering, $S Y=S t r a w$ yield, TGW = Thousand grain weight.

\section{Genetic variability}

The results revealed considerable phenotypic and genotypic variance among the genotypes for the traits under consideration. The value of GCV was high for thousand grain weight, moderate for leaf area, effective tiller, straw yield, grain yield, panicle length and days of flowering and low for plant height, chlorophyll and fertility percent. The value of PCV was high for thousand grain weight, leaf area, effective tiller, straw yield and grain yield and moderate for panicle length, days of flowering, plant height and chlorophyll and low for fertility percent. High GCV and PCV indicate that there is possibility of traits improved through selection. Low value indicates that there is need for creation of variability either by hybridization or mutation followed by selection

Plant height $(0.68)$, leaf area (0.64), effective tiller $(0.72)$, panicle length $(0.76)$, days of flowering (0.95) and thousand grain weight $(0.94)$ are highly heritable traits. Similar results were reported by Kaul and Kumar (1982); Yildirim (2006) and Mohsin et al. (2009) for anthesis days, thousand grain weight, plant height, effective tillers per $\mathrm{m}^{2}$ which indicates that traits under study are less influenced by environment in their expression. Chlorophyll content $(0.34)$, straw yield $(0.35)$ and grain yield $(0.23)$ are moderately heritable traits whereas fertility percent $(0.10)$ is low heritable traits.

Table 5 - Genetic variability, heritability and genetic advance

\begin{tabular}{|c|c|c|c|c|c|c|}
\hline Traits & Gen-sd & Phe-sd & GCV & PCV & $\mathrm{H}$ & GAM \\
\hline plant height & 12.59 & 15.31 & 9.02 & 10.97 & 0.68 & 15.25 \\
\hline Leaf area & 6.73 & 8.39 & 19.23 & 23.97 & 0.64 & 31.79 \\
\hline Chlorophyll content & 2.53 & 4.30 & 7.37 & 12.52 & 0.35 & 8.94 \\
\hline Effective tillers & 33.94 & 39.88 & 17.99 & 21.15 & 0.72 & 31.54 \\
\hline Panicle length & 2.79 & 3.20 & 11.03 & 12.65 & 0.76 & 19.80 \\
\hline Days to $50 \%$ flowering & 15.06 & 15.41 & 15.8 & 16.26 & 0.95 & 31.97 \\
\hline fertility percent & 2.23 & 6.79 & 2.56 & 7.78 & 0.11 & 1.73 \\
\hline Thousand grain weight & 5.88 & 6.06 & 22.48 & 23.17 & 0.94 & 44.94 \\
\hline Straw yield & 839.22 & 1408.3 & 14.59 & 24.48 & 0.36 & 17.91 \\
\hline Grain yield & 582.65 & 1192.2 & 13.70 & 28.04 & 0.24 & 13.80 \\
\hline
\end{tabular}

Note: Gen-sd = genotypic standard deviation, Phe-sd = phenotypic standard deviation, GCV = Genotypic coefficient of variation, $P C V=$ Phenotypic coefficient of variation, $H=$ Heritability, $G A=$ Genetic advance, $G A M=$ Genetic advance as percentage of mean. 
Genetic advance as percent of mean was, however, highest for thousand grain weight followed by days of flowering, leaf area and effective tillers. Moderate for panicle length, straw yield, panicle height and grain yield whereas low magnitude of genetic advance as percent of mean was observed for chlorophyll content and fertility percent which indicates control of non-additive gene action on these traits and heterosis breeding will be useful. High heritability coupled with high genetic advance as percent mean was observed for thousand grain weight and days of flowering, leaf area and effective tiller which indicate the control of additive gene of action and a greater scope of selection for these four traits. Similar result was observed by Bose et al. (2007) for thousand grain weight.

\section{CONCLUSION}

In terms of grain yield no variation was found among genotypes and with check variety and selection should be done based on yield attributing traits for further trials. The highest value of leaf area at 60 DAT and panicle length showed positive direct effect and also showed positive correlation with grain yield. Therefore, it should be considered for selection in breeding program. High heritability coupled with high genetic advance as percent mean was observed for thousand grain weight, days of flowering, leaf area and effective tillers per $\mathrm{m}^{2}$ which indicate the control of additive gene of action and these traits can be used in further trails as there is higher expression of traits and genotypes was recreated in each generation.

\section{ACKNOWLEDGEMENTS}

Authors were grateful to National Agricultural Research Council (NARC) and IRRI for providing research materials and RD-TEC for providing technical support to carry out this research work.

\section{CONFLICT OF INTERESTS}

Authors had not declared any conflict of interest.

\section{REFERENCES}

1. Agahi, K., Fotokian, M.H. and E. Farshadfar. 2007. Correlation and path analysis of some yield related traits in rice genotypes (Oryza sativa L.).Asian Journal of Plant Sciences, 6 (3)513-517.

2. Bhatt, B.P., Aryal, N. Neupane, S.S. and Poudel. S. 2016.Variability, correlation and path coefficient analysis of rice (Oryza sativa L.). International Journal of scientific and engineering research, 7 (8).

3. Bose, L. K., Das, S., Pradhan, S. K., Subudhi, H., Singh, S. \& Singh, O. 2007. Genetic variability of quality characters and grain yield in lowland rice genotypes of Eastern India. Korean Journal of Breeding Science, 39, 39-44.

4. Chandra, B. S. Reddy, T.D Ansari, N.A and Kumar, S.S. 2009. Correlation and path coefficient analysis for yield and yield components in rice (Oryza sativa L.)Agricultural science Digest. 29 (1): 45-47.

5. Gautam, D., B Kandel, B. P., Adhikari, B.B. (2018). Performance of rice genotypes in western mid hill of Nepal. J. Plant Breed. Genet. 06 (03) 2018. 111-116.

6. Falconer, D.S., and Mackay, T.F.C. (1996) An Introduction to Quantitative Genetics. $4^{\text {th }}$ ed., Prentice Hall, London.

7. Hairmansis, A., B. Kustianto, F. Supartopo and S. Suwarna. 2010. Correlation analysis of agronomic characters and grain yield of rice tidal swamp area. Indonesian Journal of Agricultural Science. 11 (1):11-15.

8. International Rice Research Institute (IRRI). 2017. Website at http://www.irri.org

9. Johnson, H.W., Robinson, H.F., \& Cornstock, R.E. (1955) Estimates of environmental variability in soybeans. Agronomy Journal, 47, 314-318. 
10. Karim, D., Md. N.E.A. Siddique, U. Sarkar, Md. Z. Hasnat and Sultan. J. 2014. Phenotypic and genotypic correlation coefficient of quantitative characters and character association of aromatic rice. Journal of Bioscience and Agriculture Research, 1 (1):34-46.

11. Kole, P.C. and Hasib. K.M. 2008. Correlation and regression analysis in scented rice. Madras Agriculture Journal, 95 (1-6): 178-182.

12. Konate, K.A., A. Zongo., H. Kam and A. Andebert. 2016. Genetic variability and correlation analysis of rice (Oryza sativa L.) inbreed lines based on agro-morphological traits. African Journal of Agricultural Research, 11 (35):3340-3346.

13. Lush, J.L. 1940 Inter-size correlation regression of offspring on diary as a method of estimating heritability of characters. Proceedings American Society of Animal Production, 33, 293-301.

14. Madhavilatha, L., M. Reddi sekhar, Y. Suneetha and T. Srinivas. 2005. Genetic variability, correlation and path analysis for yield and quality traits in rice (Oryza sativa L.). Research on crops, 6 (3): 527- 534.

15. Marasis, O. P. D. 1980. Adaptability, stability performance and phenotypic, genotypic and environmental correlation in varieties and line of rice. Ph. D. thesis. Universidale Federal Viscose, Brazil, pp.1 70.

16. MoAD, (2015/16). Statistical Information On Nepalese Agriculture 2015/16.Singh Durbar, Ktm Nep: Ministry Of Agriculture and Development, Agribusiness Promotion and Statistics Division.

17. Robinson, H.F., Cornstock, R.E., \& Harvey, P.H.1949. Estimates of heritability and degree of dominance in corn. Agronomy Journal, 41, 353-359.

18. Surek, H. and Beser, N. 2003. Correlation and path coefficient analysis for some yield related traits in rice under the rice conditions Turkish J. Agriculture and Forestry. 27 (2): 77-83.

19. Sivasubramanian, S., \& Menon, M. 1973. Heterosis and inbreeding depression in rice. Advances in Agronomy, 47, 85-140.

20. Sowmiya, C.A. and M. Venkatesan. 2017. Studies on Correlation and Path Coefficient Analysis in Rice (Oryza sativa L.). Int. J. Curr. Microbiol. App. Sci 6 (9): 1757-1763.doi: https://doi.org/10.20546/ijcmas.2017.609.217. 